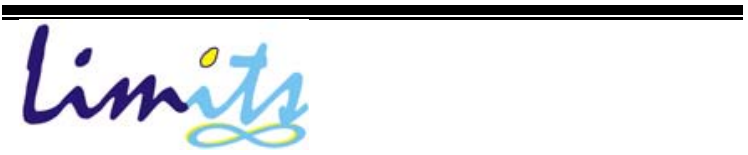

Limits: Journal of Mathematics and Its Applications

E-ISSN: 2579-8936

P-ISSN: $1829-605 \mathrm{X}$

Vol. 17, No. 1, Juli 2020, 83-95

DOI: http://dx.doi.org/10.12962/limits.v17i1.6753

\title{
Model Matematika Pemanenan Ikan dengan Kebijakan Panen Selektif
}

\author{
Lisa Risfana Sari ${ }^{1}$ * \\ ${ }^{1}$ Universitas Internasional Semen Indonesia, Gresik Indonesia \\ e-mail: lisa.sari@uisi.ac.id
}

Diajukan:9 April 2020, Diperbaiki: 17 Juni 2020, Diterima:21 Juli 2020

\begin{abstract}
Abstrak
Pengelolaan sumber daya perikanan termasuk sebagai aspek penting yang dipertimbangkan oleh negara maritim. Kelimpahan sumber daya ikan dapat dipertahankan dengan strategi penangkapan ikan yang tepat, salah satunya adalah kebijakan panen selektif. Dalam studi ini, dinamika kepadatan populasi ikan dipelajari menggunakan model predator-prey yang dimodifikasi. Proses panen selektif yang memperhitungkan usia atau ukuran ikan siap panen dinyatakan sebagai penundaan waktu dalam proses panen. Analisis model dilakukan dengan menentukan titik kesetimbangan model dan stabilitas titik keseimbangan model. Ada empat titik keseimbangan model, yang mewakili kondisi trivial, kepunahan prey, kepunahan predator, dan eksistensi predator-prey. Perilaku dinamis model diilustrasikan melalui simulasi numerik dengan beberapa skenario. Hasil simulasi numerik menunjukkan bahwa waktu tunda mempengaruhi stabilitas beberapa titik setimbang, sehingga menghasilkan dinamika populasi yang lebih beragam.
\end{abstract}

Kata Kunci: pemanenan ikan, predator-prey, simulasi numerik, waktu tunda.

\begin{abstract}
The abundance of fish resources can be maintained with the right fishing strategies, one of which is the selective harvest policy. In this study, the dynamics of fish population density were studied using a modified predator-prey model. The selective harvest process that takes into account the age or size at which fish are ready to harvest is expressed as a time delay in the harvesting process. The model analysis involves determining the model's equilibrium point and the model's equilibrium point stability. There are four equilibrium points of the model, which represent trivial conditions, prey extinction, predator extinction, and predator-prey existence. The dynamic behavior of the model is illustrated through numerical simulations with several scenarios. Numerical simulation results show that time delay affects the stability of several equilibrium points, resulting in a more diverse population dynamics.
\end{abstract}

Keywords: fish harvesting, predator-prey, numerical simulation, time delay.

\section{Pendahuluan}

Ekologi akuatik adalah sub-disiplin ekologi yang mempelajari interaksi atau keterkaitan organisme yang hidup di perairan dengan lingkungannya. Termasuk didalamnya ialah lautan, muara, danau, kolam, dan sungai. Lingkungan alami mempengaruhi pertumbuhan dan 
perkembangan organisme hidup. Tentu saja, hal ini berkontribusi pada kelangsungan hidup organismenya [1].

Ikan adalah salah satu organisme akuatik. Ekologi akuatik memiliki posisi yang berpengaruh di bidang perikanan. Manfaat mempelajari ekologi perairan adalah mengetahui berbagai jenis ekosistem perairan, juga parameter atau faktor pembatas lingkungan bagi organisme yang hidup di dalamnya [1]. Hal ini dapat digunakan untuk mendukung manajemen sumber daya perikanan.

Sumber daya perikanan berpotensi untuk meningkatkan pertumbuhan dan kekayaan negara. Penerapan manajemen perikanan yang efektif dapat meningkatkan produktivitas perikanan. Kelimpahan sumber daya perikanan yang dikelola dengan baik dapat menjamin pemanfaatan berkelanjutan untuk kesejahteraan masyarakat. Oleh karena itu, diperlukan kebijakan manajemen sumber daya untuk menghindari eksploitasi ikan dan menjaga cadangan ikan.

Pemanenan ikan mempengaruhi kelimpahan sumber daya ikan dan hasil perikanan maksimum. Kebijakan pemanenan selektif adalah upaya untuk melestarikan sumber daya ikan. Dalam pemanenan selektif, ikan yang siap panen adalah ikan yang telah mencapai ukuran atau usia standar tertentu [2]-[5]. Hal ini dilakukan untuk memastikan keberadaan, ketersediaan, dan keberlanjutan sumber daya ikan sekaligus mempertahankan dan meningkatkan kualitas nilai dan keanekaragaman.

Pemodelan matematika menggunakan model predator-prey telah banyak digunakan dalam studi ekologi akuatik. Model predator-prey digunakan untuk mempelajari interaksi dua spesies ikan dalam suatu ekosistem yang dibagi menjadi spesies mangsa (prey) dan spesies predator. Hasil beberapa penelitian menunjukkan bahwa model dapat menggambarkan dinamika populasi ikan, menjelaskan pengaruh berbagai faktor pada populasi, serta memprediksi perilaku dinamis populasi [5]-[9].

Berkaitan dengan manajemen perikanan, penelitian ini dilakukan untuk menguji bagaimana kebijakan panen selektif mempengaruhi kelimpahan sumber daya ikan dari perspektif model matematika. Dalam studi ini, model predator-prey yang dimodifikasi diformulasikan dengan fungsi respon Beddington-DeAngelis dalam pemangsaan dan penundaan panen pada mangsa (prey), yang memperhitungkan pemanenan ikan secara selektif di atas usia atau ukuran tertentu. Analisis dinamis model dilakukan untuk melacak kondisi keseimbangan dalam jangka panjang. Pada bagian terakhir, pengaruh seleksi pada panen terhadap hasil perikanan dibahas dalam serangkaian simulasi. 


\section{Model Matematika}

Pemodelan matematika dikembangkan berdasarkan model predator-prey yang diusulkan oleh [5], [6], [10]-[14]. Model dinyatakan dalam sistem diferensial tundaan nonlinier dengan dua variabel yang merupakan fungsi terhadap waktu. Fungsi tersebut mewakili populasi kepadatan mangsa (prey) dan populasi kepadatan predator. Model predator-prey yang dimodifikasi dijelaskan dalam sistem pada Persamaan (1).

$$
\begin{aligned}
& \frac{d x(t)}{d t}=r_{1} x(t)-p x(t)^{2}-f(x(t), y(t))-H_{1}(x(t-\tau)), \\
& \frac{d y(t)}{d t}=y(t)\left(r_{2}-\frac{\beta y(t)}{x(t)+k}\right)-H_{2}(y(t)) .
\end{aligned}
$$

Dalam sistem (1), parameter $r_{1}$ dan $r_{2}$ masing-masing menunjukkan tingkat pertumbuhan intrinsik mangsa dan predator. Parameter $p$ menunjukkan kekuatan persaingan di antara individu mangsa, $\beta$ menunjukkan nilai maksimum tingkat pengurangan per kapita predator, dan $k$ mengukur tingkat perlindungan lingkungan terhadap predator.

Pemangsaan prey oleh predator digambarkan sebagai fungsi respon Beddington-DeAngelis pada Persamaan (2). Pemilihan fungsi respon ini dilatarbelakangi asumsi bahwa populasi prey tersaturasi, dimana laju pemangsaan akan menurun seiring dengan bertambahnya populasi baik prey maupun predator. Hal ini sesuai dengan model yang diusulkan oleh [11], [12], [14].

$$
f(x(t), y(t))=\frac{\alpha x(t) y(t)}{a+b x(t)+c y(t)}
$$

Parameter $\alpha$ adalah nilai maksimum yang tingkat pengurangan prey per kapita dan $a$ merupakan tingkat perlindungan lingkungan untuk mempertahankan kelangsungan hidup prey. Sementara itu, parameter $b$ dan $c$ koefisien terkait dengan kontak mutual diantara prey dan predator.

Populasi ikan termasuk prey dan predator dipanen menggunakan fungsi panen linier. Diasumsikan predator adalah ikan yang berukuran lebih besar atau berusia lebih dewasa daripada spesies prey. Pemanenan selektif memastikan pembatasan untuk menangkap ikan sebelum mencapai ukuran atau usia tertentu [3]. Ini diungkapkan dengan memasukkan penundaan waktu dalam masa panen [2], [4]-[6]. Didasari oleh hal tersebut, kebijakan pemanenan selektif pada model hanya diterapkan untuk spesies prey. Fungsi panen untuk kedua spesies dijelaskan sebagai berikut.

$$
\begin{gathered}
H_{1}(x(t-\tau))=q_{1} E_{1} x(t-\tau) \\
H_{2}(y(t))=q_{2} E_{2} y(t)
\end{gathered}
$$


Parameter $q_{1}$ and $q_{2}$ masing-masing menunjukkan koefisien penangkapan dari prey dan predator. Sementara itu, parameter $E_{1}$ dan $E_{2}$ menunjukkan upaya panen untuk populasi prey dan predator.

\section{Hasil dan Pembahasan}

Pada bagian ini akan dibahas hasil analisis numerik beserta simulasinya. Kedua hasil tersebut digunakan untuk menggambarkan perilaku dinamis populasi.

\subsection{Titik Kesetimbangan}

Titik kesetimbangan model diperoleh dari solusi setimbang saat $\frac{d x(t)}{d t}=0$ dan $\frac{d y(t)}{d t}=0$. Diperoleh empat titik kesetimbangan model yaitu;

1. titik trivial $I_{0}=(0,0)$,

2. titik kepunahan prey $I_{1}=\left(0, \frac{k\left(r_{2}-q_{2} E_{2}\right)}{\beta}\right)$,

3. titik kepunahan predator $I_{2}=\left(\frac{r_{1}-q_{1} E_{1}}{p}, 0\right)$,

4. titik eksistensi prey dan predator $I_{3}=\left(\Delta, \frac{\left(r_{2}-q_{2} E_{2}\right)(\Delta+k)}{\beta}\right)$,

dimana $\Delta$ adalah akar positif riil dari persamaan berikut

$$
P(\Delta)=p\left(c \Delta_{2}+b \beta\right) \Delta^{2}+\left(a p \beta+\alpha \Delta_{2}-b \beta \Delta_{1}+c k p \Delta_{2}-c \Delta_{1} \Delta_{2}\right) \Delta-c k \Delta_{1} \Delta_{2}-a \beta \Delta_{1}+\alpha k \Delta_{2}
$$

dengan

$$
\begin{aligned}
& \Delta_{1}=r_{1}-q_{1} E_{1} \\
& \Delta_{2}=r_{2}-q_{2} E_{2}
\end{aligned}
$$

Titik kesetimbangan mewakili kepadatan populasi prey dan predator pada masa setimbang. Titik $I_{0}$ menggambarkan kepunahan bagi prey dan predator. Titik ini selalu eksis. Titik $I_{1}$ dan $I_{2}$ menggambarkan kepunahan salah satu spesies sementara yang lain bertahan. Titik $I_{1}$ dan $I_{2}$ masing-masing eksis jika hanya jika $r_{2}-q_{2} E_{2}>0$ dan $r_{1}-q_{1} E_{1}>0$. Sementara itu, titik $I_{3}$ menjelaskan bahwa kedua spesies ini bertahan hidup. Titik ini eksis jika dan hanya jika $r_{2}-q_{2} E_{2}>0$ dan $r_{1}-q_{1} E_{1}>0$. 


\subsection{Kestabilan Lokal Titik Kesetimbangan}

Linearisasi sistem persamaan diferensial tundaan diperlukan dalam analisis kestabilan titik kesetimbangan. Persamaan karakteristik dari sistem terlinearisasi model (1) dinyatakan dalam Persamaan (4).

$$
\left|\begin{array}{cc}
j_{11}-\lambda & j_{12} \\
j_{21} & j_{22}-\lambda
\end{array}\right|=0
$$

dimana

$$
\begin{aligned}
& j_{11}=r_{1}-2 p x^{*}-\frac{\alpha y^{*}}{a+b x^{*}+c y^{*}}+\frac{\alpha b x^{*} y^{*}}{\left(a+b x^{*}+c y^{*}\right)^{2}}-e^{-\lambda \tau} q_{1} E_{1} \\
& j_{12}=-\frac{\alpha x^{*}}{a+b x^{*}+c y^{*}}+\frac{\alpha c x^{*} y^{*}}{\left(a+b x^{*}+c y^{*}\right)^{2}} \\
& j_{21}=\frac{\beta\left(y^{*}\right)^{2}}{\left(x^{*}+k\right)^{2}} \\
& j_{22}=r_{2}-\frac{2 \beta y^{*}}{x^{*}+k}-q_{2} E_{2}
\end{aligned}
$$

Penentuan kestabilan lokal pada model sistem persamaan diferensial tundaan tidak mudah. Oleh karenanya, digunakan analisis numerik sebagai acuan. Penentuan nilai parameter pada analisis tersebut merujuk pada [5]-[9], [15].

Berkaitan dengan syarat eksistensi titik kesetimbangan, diperoleh empat macam kondisi yang digunakan untuk menentukan dan mengamati kestabilan titik kesetimbangan. Keempat kondisi tersebut dijelaskan berikut.

1. Kondisi $r_{1}<q_{1} E_{1}$ dan $r_{2}<q_{2} E_{2}$

Kondisi ini mewakili keadaan over eksploitasi kedua spesies, dengan laju pertumbuhan lebih kecil dibandingkan upaya penangkapan ikan. Pada kondisi ini digunakan nilai parameter $\quad r_{1}=5 \times 10^{-3}, \quad q_{1}=0.1 \times 10^{-3}, \quad E_{1}=72, \quad r_{2}=8 \times 10^{-3}, \quad q_{2}=0.5 \times 10^{-3}$, dan $E_{2}=22$. Terdapat satu titik kesetimbangan eksis yaitu $I_{0}$. Persamaan karakteristik pada titik $I_{0}=(0,0)$ adalah

$$
p(\lambda)=\left(\lambda^{2}-2 \times 10^{-3} \lambda-15 \times 10^{-6}\right)+\left(7.2 \times 10^{-3} \lambda+21.6 \times 10^{-6}\right) e^{-\lambda \tau}=0 .
$$

Berdasarkan Persamaan (5) untuk $\tau=0$, diperoleh bagian riil akar persamaan karakteristik bernilai negatif, sehingga titik $I_{0}$ bersifat stabil asimtotik lokal. Sementara itu, untuk 
$\tau \neq 0$, diperoleh $\tau_{0}=155.0260787$. Nilai kritis ini merupakan batas perubahan kestabilan. Kestabilan titik kesetimbangan sistem dijamin jika $\operatorname{Re}(\lambda)<0$ untuk semua akar karakteristik. Titik kesetimbangan kehilangan stabilitasnya hanya jika nilai $\tau$ melewati nilai kritis tundaan yang diperoleh dari $p(i \omega)=0$. Perubahan kestabilan bisa terjadi antara kondisi stabil dan tidak stabil atau sebaliknya [16]. Perubahan kestabilan ini lebih lanjut akan digambarkan melalui simulasi numerik.

2. Kondisi $r_{1}<q_{1} E_{1}$ dan $r_{2}>q_{2} E_{2}$

Situasi yang terjadi pada kondisi berikut adalah over eksploitasi hanya terjadi pada spesies prey. Terdapat dua titik kesetimbangan yang eksis, yaitu $I_{0}$ dan $I_{1}$. Disini digunakan nilai parameter yaitu $r_{1}=5 \times 10^{-3}, q_{1}=0.3 \times 10^{-3}, E_{1}=22, r_{2}=8 \times 10^{-3}, q_{2}=0.5 \times 10^{-3}$, dan $E_{2}=12$. Substitusi masing-masing titik kesetimbangan pada persamaan (4) menghasilkan persamaan karakteristik berikut

$$
\begin{aligned}
& \left(\lambda^{2}-7 \times 10^{-3} \lambda+10^{-5}\right)+\left(6.6 \times 10^{-3} \lambda-13.2 \times 10^{-6}\right) e^{-\lambda \tau}=0 \text { untuk } I_{0} \\
& \left(\lambda^{2}+0.0029 \lambda-9.9 \times 10^{-6}\right)+\left(0.0066 \lambda+13.2 \times 10^{-6}\right) e^{-\lambda \tau}=0 \text { untuk } I_{1} .
\end{aligned}
$$

Solusi Persamaan (6) dan (7) untuk $\tau=0$ menunjukkan bahwa titik $I_{0}$ tidak stabil, dimana terdapat akar dengan bagian riil positif, sedangkan $I_{1}$ stabil asimtotik lokal. Lebih lanjut untuk $\tau \neq 0$, hasil menunjukkan tidak terdapat nilai kritis tundaan. Akibatnya, tidak ditemukan terjadinya perubahan kestabilan pada kedua titik kesetimbangan.

3. Kondisi $r_{1}>q_{1} E_{1}$ dan $r_{2}<q_{2} E_{2}$

Berbeda dengan kondisi kedua, pada kondisi ketiga terjadi over eksploitasi spesies predator. Titik kesetimbangan $I_{0}$ dan $I_{2}$ eksis pada kondisi tersebut. Pengamatan dilakukan dengan nilai parameter $r_{1}=6 \times 10^{-3}, q_{1}=0.3 \times 10^{-3}, E_{1}=12, r_{2}=3 \times 10^{-3}$, $q_{2}=0.2 \times 10^{-3}$, dan $E_{2}=22$. Persamaan karakteristik untuk masing-masing titik kesetimbangan adalah

$$
\begin{gathered}
\left(\lambda^{2}-4.6 \times 10^{-3} \lambda+8.4 \times 10^{-6}\right)+\left(5.04 \times 10^{-3} \lambda+3.6 \times 10^{-6}\right) e^{-\lambda \tau}=0 \text { untuk } I_{0} \\
\left(\lambda^{2}+0.002 \lambda-1.7 \times 10^{-6}\right)+\left(0.0036 \lambda+5 \times 10^{-6}\right) e^{-\lambda \tau}=0 \text { untuk } I_{2} .
\end{gathered}
$$

Perhitungan dengan $\tau=0$ untuk Persamaan (8) dan (9) mengungkapkan bahwa $I_{0}$ tidak stabil dan $I_{2}$ stabil asimtotik lokal. Kemudian untuk $\tau \neq 0$, solusi Persamaan (8) dan (9) 
mengkonfirmasi bahwa tidak terdapat nilai kritis tundaan. Dengan kata lain, tidak terjadi perubahan kestabilan pada kedua titik kesetimbangan.

4. Kondisi $r_{1}>q_{1} E_{1}$ dan $r_{2}>q_{2} E_{2}$

Kondisi terakhir ini menggambarkan laju pertumbuhan kedua spesies ikan masih lebih tinggi dibandingkan upaya penangkapannya. Hal ini juga mewakili kondisi ketika kelimpahan ikan untuk kedua spesies dapat dipertahankan. Keempat titik kesetimbangan eksis pada kondisi tersebut. Nilai parameter yang digunakan untuk analisis adalah $r_{1}=6 \times 10^{-3}, q_{1}=0.3 \times 10^{-3}, E_{1}=12, r_{2}=7 \times 10^{-3}, q_{2}=0.2 \times 10^{-3}$, dan $E_{2}=22$. Untuk masing-masing titik, persamaan karakteristiknya adalah

$$
\begin{aligned}
& \left(\lambda^{2}-8.6 \times 10^{-3} \lambda+15.6 \times 10^{-6}\right)+\left(9.36 \times 10^{-3} \lambda+3.6 \times 10^{-6}\right) e^{-\lambda \tau}=0 \text { untuk } I_{0} \\
& \left(\lambda^{2}-3.6 \times 10^{-3} \lambda+3.2 \times 10^{-6}\right)+\left(3.6 \times 10^{-3} \lambda+9.4 \times 10^{-6}\right) e^{-\lambda \tau}=0 \text { untuk } I_{1} \\
& \left(\lambda^{2}-3.4 \times 10^{-3} \lambda+15.6 \times 10^{-6}\right)+\left(3.4 \times 10^{-3} \lambda+9.4 \times 10^{-6}\right) e^{-\lambda \tau}=0 \text { untuk } I_{2} \\
& \left(\lambda^{2}-3.6 \times 10^{-3} \lambda+3.2 \times 10^{-6}\right)+\left(3.6 \times 10^{-3} \lambda+9.4 \times 10^{-6}\right) e^{-\lambda \tau}=0 \text { untuk } I_{3}
\end{aligned}
$$

Perolehan solusi untuk $\tau=0$ pada Persamaan (10)-(13) menunjukkan bahwa titik kesetimbangan $I_{0}, I_{1}$, dan $I_{2}$ tidak stabil. Sementara itu, titik $I_{3}$ stabil asimtotik lokal. Analisis dengan $\tau \neq 0$ mengungkapkan tidak terdapat nilai kritis tundaan sehingga perubahan kestabilan tidak terjadi.

\subsection{Simulasi Numerik}

Simulasi dilakukan pada keempat kondisi, dengan bantuan software Matlab. Studi numerik menunjukkan bahwa eksploitasi berlebihan dapat menyebabkan kepunahan populasi ikan. Diilustrasikan pada Gambar 1, jika $r_{1}<q_{1} E_{1}$ dan $r_{2}<q_{2} E_{2}$ maka semua solusi Sistem (1) konvergen ke $I_{0}$ untuk $\tau=0$.

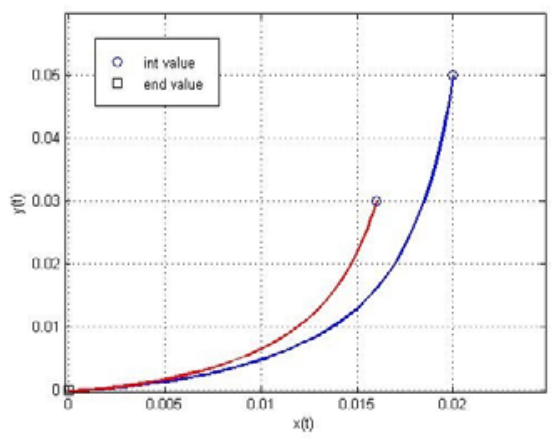

Gambar 1. Potret fase untuk $r_{1}<q_{1} E_{1}$ dan $r_{2}<q_{2} E_{2}$ saat $\tau=0$ 
Untuk mencegah situasi tersebut, dibutuhkan penundaan waktu panen $\tau$ pada prey yang cukup besar. Tampak bahwa terdapat perubahan kestabilan $I_{0}$ dengan peningkatan $\tau$ (Lihat Gambar 2). Dalam hal ini, untuk nilai tunda $\tau$ yang lebih besar dari nilai kritis $\tau_{0}$, populasi prey dapat dilindungi dari kepunahan.

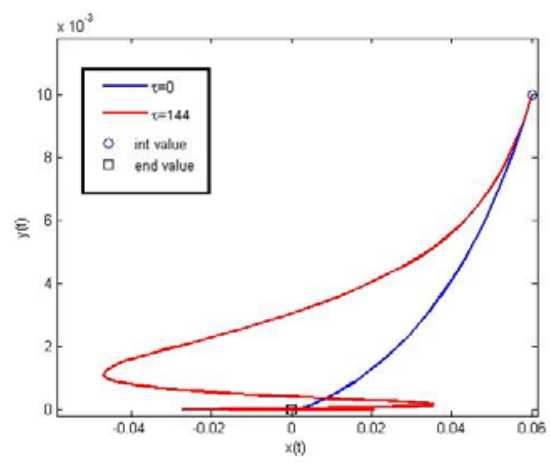

(i) $\tau=144$

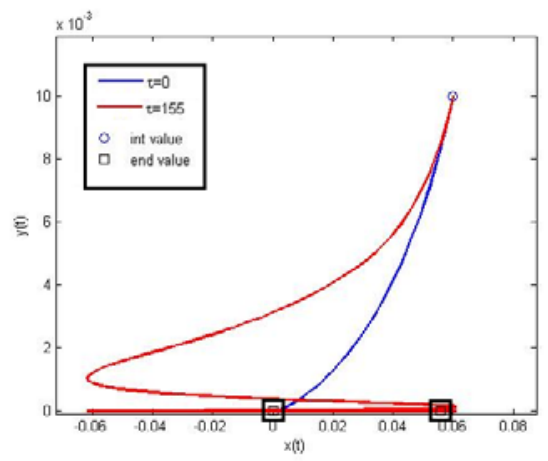

(iii) $\tau=155$

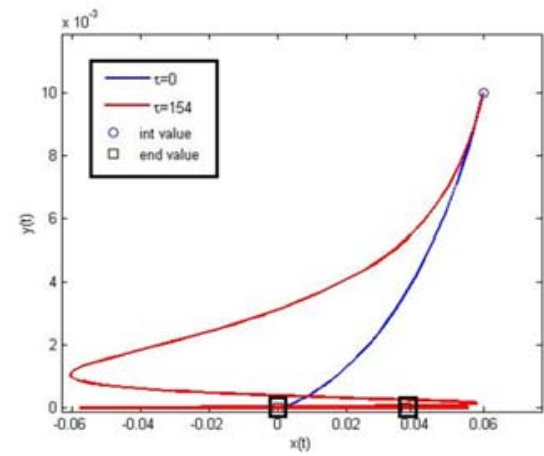

(ii) $\tau=154$

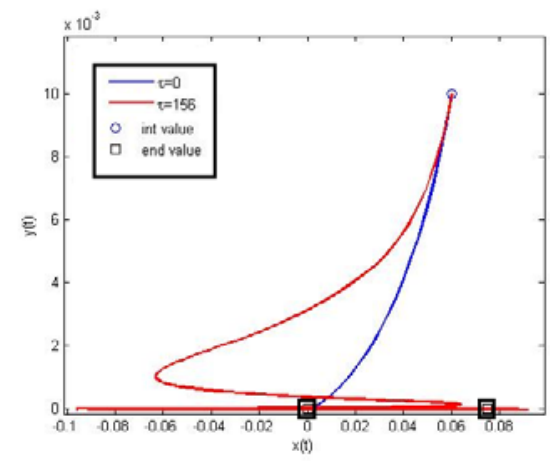

(iv) $\tau=156$

Gambar 2. Solusi sistem untuk $r_{1}<q_{1} E_{1}$ dan $r_{2}<q_{2} E_{2}$

Gambar 3 menunjukkan perilaku osilasi pada kepadatan populasi mangsa (prey). Osilasi semakin besar ketika nilai $\tau$ lebih besar dari 155. Hal ini mengindikasikan bahwa $\tau=155$ merupakan suatu nilai kritis tundaan yang mewakili waktu tunda panen minimum untuk menghambat laju penurunan populasi ikan. Waktu tunda panen dapat dikaitkan dengan kebijakan panen selektif berdasarkan ukuran atau usia siap panen ikan. Namun demikian, osilasi terjadi diantara nilai nol sehingga hasil ini kurang dapat mewakili kondisi nyata kepadatan populasi ikan. 


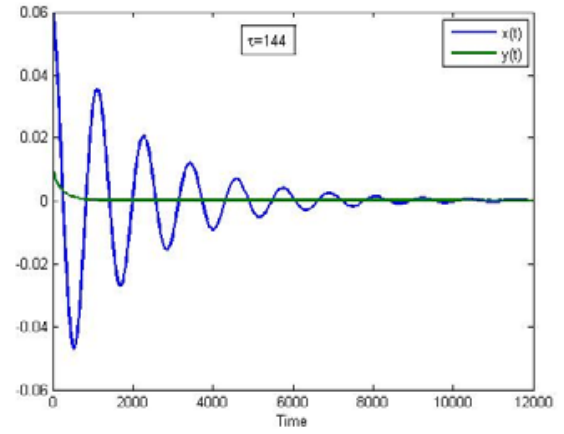

(i) $\tau=144$

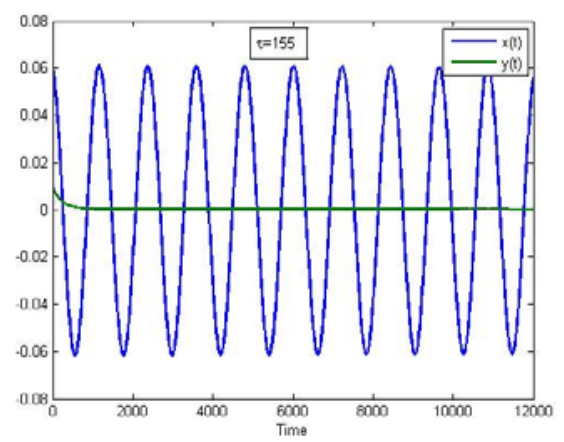

(i) $\tau=155$

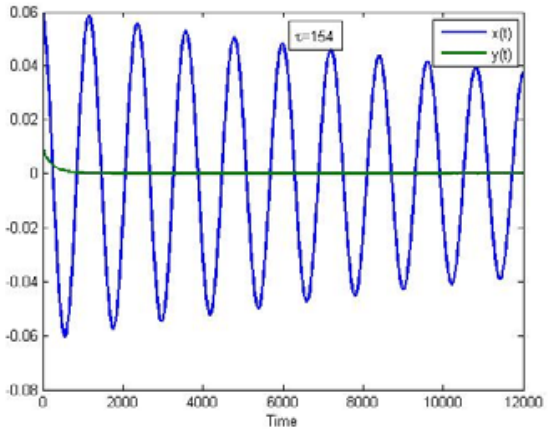

(ii) $\tau=154$

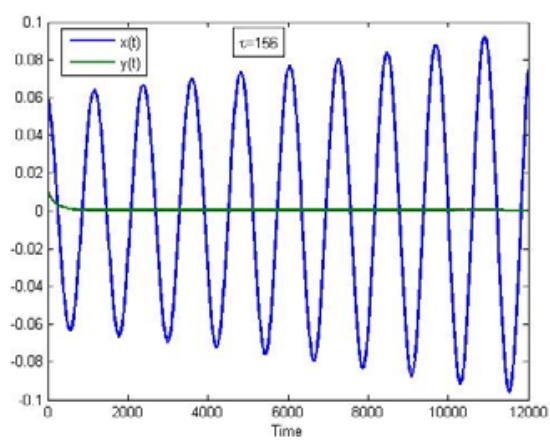

(ii) $\tau=156$

Gambar 3. Kepadatan populasi ikan untuk $r_{1}<q_{1} E_{1}$ dan $r_{2}<q_{2} E_{2}$

Gambar 4 mengungkapkan jika $r_{1}<q_{1} E_{1}$ dan $r_{2}>q_{2} E_{2}$ maka solusi Sistem (1) konvergen ke $I_{1}$ untuk $\tau \geq 0$. Hal ini didukung Gambar 5 yang menunjukkan bahwa walaupun terjadi osilasi pada kepadatan populasi mangsa saat $\tau>0$, besar osilasi semakin kecil dan menjadi setimbang pada nilai nol. Sementara itu, jika $r_{2}<q_{2} E_{2}$ dan $r_{1}>q_{1} E_{1}$ maka solusi Sistem (1) konvergen ke $I_{2}$ untuk $\tau \geq 0$ (lihat Gambar 6). Ketiganya mewakili kondisi kepunahan salah satu spesies ikan.

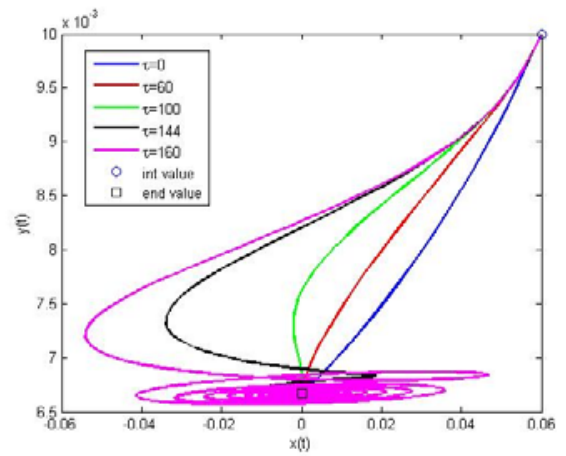

Gambar 4. Solusi sistem untuk $r_{1}<q_{1} E_{1}$ dan $r_{2}>q_{2} E_{2}$ untuk $\tau=[0,60,100,144,160]$ 


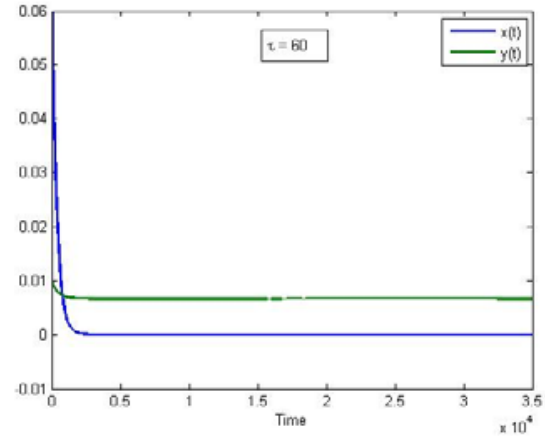

(i) $\tau=60$

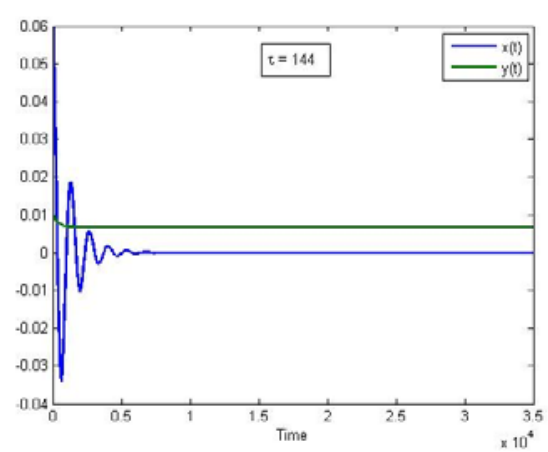

(i) $\tau=144$

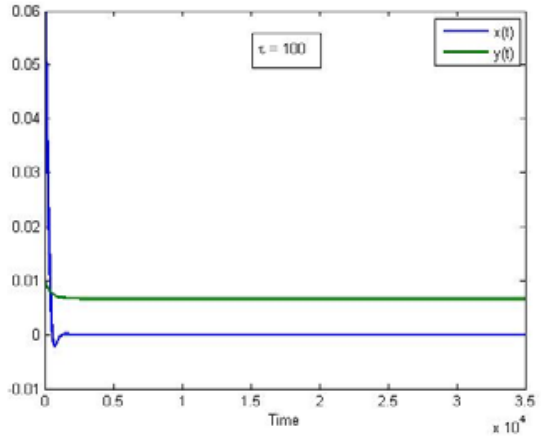

(ii) $\tau=100$

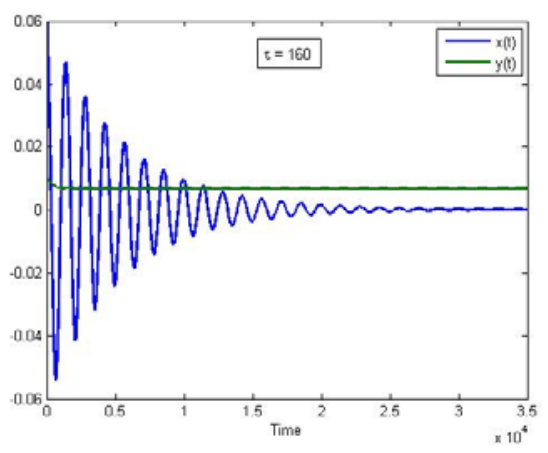

(ii) $\tau=160$

Gambar 5. Kepadatan populasi ikan untuk $r_{1}<q_{1} E_{1}$ dan $r_{2}>q_{2} E_{2}$

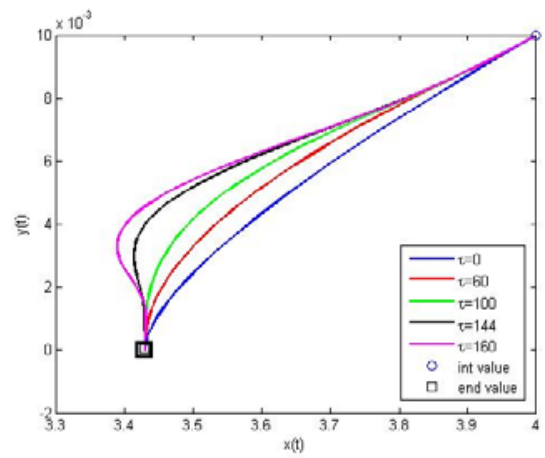

Gambar 6. Solusi sistem untuk $r_{1}>q_{1} E_{1}$ dan $r_{2}<q_{2} E_{2}$ untuk $\tau=[0,60,100,144,160]$

Eksploitasi berlebihan terhadap suatu spesies memicu penurunan kepadatan populasi spesies tersebut dan bahkan dapat menyebabkan kepunahan. Tampak pada Gambar 4 dan 6 bahwa penundaan panen tidak mempengaruhi perubahan stabilitas sehingga adanya kebijakan panen selektif pun tidak mampu menghambat kepunahan spesies tersebut.

Kondisi dengan populasi ikan tidak tereksploitasi yaitu $r_{1}>q_{1} E_{1}$ dan $r_{2}>q_{2} E_{2}$ ditunjukkan pada Gambar 7. Diilustrasikan bahwa solusi Sistem (1) konvergen ke $I_{3}$ untuk $\tau \geq 0$. Dalam 
situasi ini, kedua spesies dapat dilindungi dari kepunahan. Hal ini dikarenakan populasi keduanya tetap ada atau mampu bertahan hingga pada kondisi setimbang.

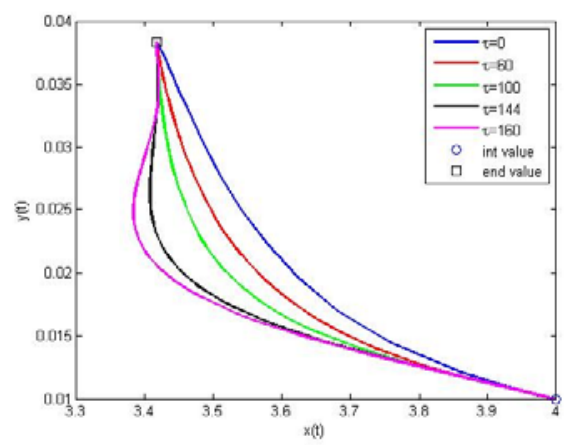

Gambar 7. Solusi sistem untuk $r_{1}>q_{1} E_{1}$ dan $r_{2}>q_{2} E_{2}$ untuk $\tau=[0,60,100,144,160]$

Eksploitasi berlebihan dalam sumber daya perikanan terjadi ketika sumber daya dipanen pada tingkat yang lebih cepat daripada yang laju regenerasi. Eksploitasi berlebihan merusak ekosistem dan dapat menyebabkan degradasi. Degradasi terjadi ketika net supply ekosistem rusak sehingga tidak dapat pulih sendiri dalam periode yang wajar setelah tindakan perusakan dihentikan [17]. Untuk menjaga keanekaragaman hayati, eksploitasi berlebihan harus dikontrol oleh kebijakan pemanenan yang tepat.

\section{Simpulan}

Dalam penelitian ini, dampak kebijakan panen selektif terhadap kelimpahan sumber daya ikan diselidiki. Model dirumuskan untuk memahami mekanisme panen ikan yang tepat untuk menjaga stok ikan. Mekanisme tersebut terkait dengan tindakan pencegahan eksploitasi sumber daya ikan yang berlebihan.

Eksploitasi berlebihan untuk kedua spesies membahayakan ekosistem dan mengancam kelimpahan sumber daya perikanan. Membatasi jumlah penangkapan ikan atau panen dengan upaya pengelolaan tangkapan adalah salah satu cara untuk melindungi stok ikan dari eksploitasi berlebihan. Untuk menjaga stok ikan, waktu tunda panen dengan durasi waktu tertentu diperlukan. Hal ini diwakili oleh nilai tunda kritis. Namun, ketika eksploitasi berlebihan hanya terjadi pada salah satu spesies, penundaan panen tidak dapat mencegah penurunan kepadatan populasi sehingga stok ikan masih berisiko habis. Oleh karena itu, untuk mengatasi eksploitasi sumber daya perikanan yang berlebihan, kebijakan pemanenan selektif juga perlu didukung oleh kebijakan upaya penangkapan ikan terbatas. 
Meskipun model tersebut telah memberikan interpretasi yang jelas tentang berbagai fenomena yang terkait dengan pengelolaan sumber daya perikanan, model ini mungkin belum memenuhi batasan positif untuk solusi. Analisis stabilitas global dari keseimbangan belum dipelajari dalam analisis model. Selain itu, waktu tunda panen untuk predator perlu dipertimbangkan dalam model.

\section{Ucapan Terima Kasih}

Ucapan terima kasih diberikan kepada Universitas Internasional Semen Indonesia yang telah mendukung penelitian ini melalui Hibah Riset Bersaing UISI 2019.

\section{Daftar Pustaka}

[1] H. Latuconsina and U. G. M. Press, Ekologi Perairan Tropis: Prinsip Dasar Pengelolaan Sumber Daya Hayati Perairan. UGM PRESS, 2019.

[2] A. Mukhopadhyay, J. Chattopadhyay, and P. K. Tapaswi, "Selective harvesting in a two species fishery model,” Ecol. Modell., 1997, doi: 10.1016/S0304-3800(96)00019-1.

[3] M. Breen, N. Graham, M. Pol, P. He, D. Reid, and P. Suuronen, "Selective fishing and balanced harvesting," Fish. Res., 2016, doi: 10.1016/j.fishres.2016.03.014.

[4] D. Pal, G. P. Samanta, and G. S. Mahapatra, "Selective harvesting of two competing fish species in the presence of toxicity with time delay," Appl. Math. Comput., 2017, doi: 10.1016/j.amc.2017.05.069.

[5] Y. Pei, M. Chen, X. Liang, and C. Li, "Model-based on fishery management systems with selective harvest policies," Math. Comput. Simul., 2019, doi:

10.1016/j.matcom.2018.08.009.

[6] T. K. Kar, "Selective harvesting in a prey-predator fishery with time delay," Math. Comput. Model., 2003, doi: 10.1016/S0895-7177(03)90099-9.

[7] Y. Lv, R. Yuan, and Y. Pei, "A prey-predator model with harvesting for fishery resource with reserve area," Appl. Math. Model., 2013, doi: 10.1016/j.apm.2012.07.030.

[8] M. Li, B. Chen, and H. Ye, “A bioeconomic differential algebraic predator-prey model with nonlinear prey harvesting," Appl. Math. Model., 2017, doi: 10.1016/j.apm.2016.09.029.

[9] S. G. Mortoja and P. Panja, "Dynamics of a predator-prey model with stage-structure on both species and anti-predator behavior," Informatics Med. Unlocked, vol. 10, pp. 50-57, 2018, doi: 10.1016/j.imu.2017.12.004. 
[10] P. H. LESLIE, "SOME FURTHER NOTES ON THE USE OF MATRICES IN POPULATION MATHEMATICS,” Biometrika, 1948, doi: 10.1093/biomet/35.3-4.213.

[11] J. R. Beddington, "Mutual Interference Between Parasites or Predators and its Effect on Searching Efficiency,” J. Anim. Ecol., 1975, doi: 10.2307/3866.

[12] D. L. DeAngelis, R. A. Goldstein, and R. V. O’Neill, “A Model for Tropic Interaction,” Ecology, 1975, doi: 10.2307/1936298.

[13] M. A. Aziz-Alaoui and M. Daher Okiye, "Boundedness and Global Stability for a Predator-Prey Model with Modified Leslie-Gower and Holling-Type II Schemes,” Appl. Math. Lett., 2003, doi: 10.1016/S0893-9659(03)90096-6.

[14] S. Yu, "Global stability of a modified Leslie-Gower model with Beddington-DeAngelis functional response," Adv. Differ. Equations, vol. 2014, no. 1, pp. 1-14, 2014, doi: 10.1186/1687-1847-2014-84.

[15] F. Fitriah, A. Suryanto, and N. Hidayat, "Numerical Study of Predator-Prey Model with Beddington-DeAngelis Functional Response and Prey Harvesting,” J. Trop. Life Sci., vol. 5, no. 2, pp. 105-109, May 2015, doi: 10.11594/jtls.05.02.09.

[16] Q. Gao and H. R. Karimi, Stability, control and application of time-delay systems. Elsevier, 2019.

[17] K. Steier, Gabriela, Patel, Ed., International Farm Animal, Wildlife and Food Safety Law. 2017. 